\title{
PENAMBAHAN TEKNIK ( PROPRIOCEPTIVE NEUROMUSCULAR FACILITATION) PNF PADA LATIHAN STANDAR FISIOTERAPI LEBIH MENINGKATKAN SKOR KEMAMPUAN FUNGSIONAL DIBANDINGKAN DENGAN PENAMBAHAN TEKNIK (PROGRESSIVE RESISTANCE EXERCISE) PRE PADA LATIHAN STANDAR FISIOTERAPI PADA PASIEN PASCA OPERASI TOTAL KNEE REPLACEMENT DI DENPASAR
}

\author{
Made Indra Prasetya Permana ${ }^{1}$, Luh Made Indah Sri Handari Adiputra ${ }^{2}$, Sugijanto ${ }^{3}$, \\ Nyoman Mangku Karmaya ${ }^{4}$, Ketut Tirtayasa ${ }^{5}$, Bagus Komang Satriyasa ${ }^{6}$ \\ ${ }^{1}$ Program Studi Magister Fisiologi Keolahragaan Universitas Udayana, Denpasar \\ ${ }^{2}$ Ilmu Faal Fakultas Kedokteran Universitas Udayana, Denpasar \\ ${ }^{3}$ Fakultas Fisioterapi Universitas Esa Unggul, Jakarta \\ ${ }^{4,5,6}$ Fakultas Kedokteran Universitas Udayana, Denpasar
}

E-Mail : indra.onfire@gmail.com

\begin{abstract}
ABSTRAK
Pendahuluan: Penurunan kemampuan fungsional pada pasca Total Knee Replacement (TKR) yakni gangguan pada lutut yang mengalami kekakuan akibat peradangan pasca operasi dan dengan pemberian latihan Progressive Resistance Exercise (PRE) hanya meningkatkan kekuatan otot tungkai namun belum mampu menstimulasi proprioceptive dalam membantu meningkatkan kemampuan fungsional. Tujuan Penelitian: untuk membuktikan penambahan teknik Prorioceptive Neuromuscular Facilitation $(P N F)$ pada latihan standar fisioterapi lebih meningkatkan skor kemampuan fungsional dibandingkan penambahan Progressive Resistance Exercise (PRE) pada latihan standar fisioterapi pada pasien pasca operasi total knee replacement. Metode: Penelitian eksperimental dengan desain pre - post test grup. Jumlah sampel penelitian 20 orang dan terbagi ke dalam dua kelompok. Kelompok 1 mendapat perlakuan Progressive Resistance Exercise (PRE) dan latihan standar fisioterapi, sedangkan Kelompok 2 mendapat perlakuan Prorioceptive Neuromuscular Facilitation (PNF) dan latihan standar fisioterapi, pengukuran kemampuan fungsional dengan WOMAC Test pasca Total Knee Replacement (TKR). Hasil: Paired t-test pada ke dua kelompok dengan nilai signifikansi $\mathrm{p}=0,001(\mathrm{p}<0,05)$ dan hasil independent $t$-test pada ke dua kelompok dengan nilai signiikansi $p=0,001(\mathrm{p}<0,05)$ sehingga hasilnya pada ke dua kelompok terjadi peningkatan secara bermakna. Simpulan: Penambahan teknik PNF pada latihan standar fisioterapi lebih meningkatkan skor kemampuan fungsional dibandingkan dengan penambahan teknik PRE pada latihan standar fisioterapi pada pasien pasca operasi total knee replacement di Denpasar.
\end{abstract}

Kata Kunci : PNF, PRE, Latihan Standar Fisioterapi, Kemampuan Fungsional, TKR 


\section{THE ADDITION OF ( PROPRIOCEPTIVE NEUROMUSCULAR FACILITATION) PNF TECHNIQUES TO PHYSIOTHERAPY STANDARD EXERCISE INCREASE FUNCTIONAL ABILITY SCORES COMPARED TO THE ADDITION OF (PROGRESSIVE RESISTANCE EXERCISE) PRE TECHNIQUES TO PHYSIOTHERAPY STANDARD EXERCISES IN POST KNEE SURGERY PATIENT IN DENPASAR}

\section{ABSTRACT}

Background: Decreased functional ability in the post-Total Knee Replacement (TKR) is a disorder in the knee that experiences stiffness due to postoperative inflammation and by providing Progressive Resistance Exercise (PRE) only increases leg muscle strength but has not been able to stimulate proprioceptive in helping to improve functional ability.Purpose: to prove the addition of Prorioceptive Neuromuscular Facilitation (PNF) techniques to standard physiotherapy exercises further improved functional ability scores compared to the addition of Progressive Resistance Exercise (PRE) to standard physiotherapy exercises in postoperative patients with total knee replacement. Method: Experimental research with a group pre-post test design. The number of research samples is 20 people and divided into two groups. Group 1 received Progressive Resistance Exercise (PRE) and standard physiotherapy exercises, while Group 2 received Prorioceptive Neuromuscular Facilitation (PNF) and standard physiotherapy exercise, measuring functional ability with WOMAC Test after Total Knee Replacement (TKR). Results: Paired t-test in the two groups with a significance value of $p=0.001(\mathrm{p}<0.05)$ and independent $t$-test results in the two groups with a significance value of $p=0.001(p<0.05)$ so that the results in the two groups there was a significant increase. Conclusion: The addition of PNF techniques to physiotherapy standard exercises further improves functional ability scores compared to the addition of PRE techniques to standard physiotherapy exercises in post knee surgery patients in Denpasar.

KeyWords : PNF, PRE, Standard Fisioterapi Exercise, Functional Ability, TKR

\section{PENDAHULUAN}

Pasien pasca Total Knee Replacement (TKR) diharapkan meningkatnya kemampuan fungsional akibat berkurangnya rasa nyeri pada lutut akibat osteoarthritis atau rheumatoid arthritis stadium akhir, namun kenyataannya pasien menunjukkan defisit fungsional, defisit kekuatan otot dan imobilitas yang disebabkan pasien tidak menerima rehabilitasi medik pasca operasi ataupun tidak adanya jenis latihan yang spesifik untuk mempercepat proses pengembalian fungsi fisik pasien ${ }^{1}$.

Latihan standar untuk pasca Total Knee Replacement (TKR) terdiri dari quadriceps, harmstrings, abduktors dan adduktor $^{2}$. Rehabilitasi pasien pasca operasi baik mulai dilakukan satu hari pasca operasi dengan melakukan mobilisasi pada lutut dan latihan isometrik untuk meningkatkan kekuatan otot paha. Pemberian latihan standar fisioterapi hanya berfokus pada kontrol postural saja oleh karena itu diperlukan latihan yang bertujuan untuk meningkatkan respon tubuh terhadap perubahan posisi, agar menghasilkan respon cepat sehingga keseimbangan akan lebih baik yang akan berpengaruh terhadap peningkatan kemampuan fungsional.

\section{Proprioseptive}

Neuromuscular

Facilitation (PNF) adalah jenis latihan ketahanan dengan teknik peregangan dan kontraksi kelompok otot yang menjadi sasaran ${ }^{4}$. Proprioceptive Neuromuscular Facilitation (PNF) yang menggunakan 
kontraksi isometrik secara optimal dari kelompok otot antagonis yang memendek sampai terjadi penambahan ROM dan penurunan nyeri ${ }^{5}$. Pemberian PNF pada pasien pasca total knee replacement akan melatih proprioceptif, sehingga menimbulkan respon untuk menjaga kemampuan fisik dalam melakukan kegiatan sehari-hari. Hasil penelitian. Penelitian yang dilakukan Nakata efek jangka pendek dari pemberian PNF tersebut menyebabkan peningkatan kecapatan berjalan, panjang langkah serta penurunan rasa sakit pada pasien pasca total knee replacement sehingga kemampuan fungsional pasien juga akan ikut membaik ${ }^{5}$.

Latihan Progressive Resistance Exercise yaitu peningkatan beban latihan secara bertahap selama periode pelatihan dan harus selalu demikian dipantau oleh seorang profesional sesuai jumlah repetisi yang dapat ditoleransi setiap individu. Efek fisiologi yang ditimbulkan dari progressive resistance exercise (PRE) yaitu aliran darah ke otot yang dilatih meningkat karena kebutuhan oksigen juga meningkat, nutrisi dan protein lalu diikuti peningkatan serabut otot lurik dan kenaikan jumlah motor unit serta terjadi peningkatan koordinasi intermuscular yang menyebabkan peningkatkan kerjasama antar grup otot dan meningkatkan kekuatan otot yang berdampak pada kemampuan fungsional yang meningkat ${ }^{6}$.

Berdasarkan penelitian yang dilakukan Birgit (2014) sebelumnya mengatakan pemberian progressive resistance exercise (PRE) pada pasca TKR dapat meningkatkan kekuatan otot dalam meningkatkan kemampuan fungsional namun tidak dijelaskan PRE dapat menstimulasi proprioceptive pada otot ${ }^{14}$. Berdasarkan permasalahan di atas, peneliti tertarik untuk membandingkan penambahan teknik PNF pada latihan standar fisioterapi, untuk mengetahui pengaruh latihan PNF pasca operasi total knee replacement.

\section{METODE PENELITIAN}

Penelitian dengan rancangan eksperimental pada kelompok 1 diberikan penambahan teknik Progressive Resistance Exercise (PRE) pada Latihan standar fisioterapi, sedangkan kelompok 2 diberikan penambahan teknik Proprioceptif Neuromuscular Facilitation (PNF) pada Latihan standar fisioterapi. Pengukuran kemampuan fungsional dengan WOMAC test.

Penelitian ini dilakukan di RSUP Sanglah Denpasar. Pada bulan Februari 2020. Penelitian ini dilakukan dengan frekuensi 3 kali seminggu yang berlangsung selama 4 minggu. Sampel berjumlah 10 orang di masing-masing kelompok.

\section{HASIL PENELITIAN}

\section{Karakteristik Subjek Penelitian}

Tabel 1

Karakteristik Sampel

\begin{tabular}{ccc}
\hline \multirow{2}{*}{$\begin{array}{c}\text { Karakteristik } \\
\text { Sampel }\end{array}$} & Kelompok I & Kelompok II \\
\cline { 2 - 3 } & Rerata \pm SD & Rerata \pm SD \\
\hline Usia (tahun) & $57,3 \pm 1,70$ & $57,6 \pm 4,08$ \\
IMT $\left(\right.$ Kg/m $\left.{ }^{2}\right)$ & $25,5 \pm 0,85$ & $25,8 \pm 1,03$ \\
Sisi Operasi & $2 / 8$ & $3 / 7$ \\
(kiri/kanan) & & \\
\hline
\end{tabular}

Karakteristik sampel pada kelompok I dari segi umur dengan rerata $(57,3 \pm 1,70$ tahun), rerata IMT $(25,5 \pm 0,85)$ dengan Sisi Operasi (kiri 2 orang dan kanan 8 orang) dan karakteristik pada kelompok II dari segi umur dengan rerata $(57,6 \pm 4,08$ tahun), rerata IMT $(25,8 \pm 1,03)$ dengan Sisi Operasi (kiri 3 orang dan kanan 7 orang).

\section{Uji Normalitas dan Homogenitas}

Tabel 2

Uji Normalitas dan Homogenitas

Shapiro Wilk Test $p>0,05$

Nilai

Womac
Levene's

Test 


\begin{tabular}{cccc}
\hline \hline & & 0,113 & \\
\hline $\begin{array}{c}\text { Sebelum } \\
\text { Perlakuan } \\
\text { Sesudah }\end{array}$ & 0,469 & 0,512 \\
Perlakuan & 0,789 & 0,072 & \\
\hline
\end{tabular}

Hasil uji normalitas data, keseluruhan data memilki nilai $\mathrm{p}>0,05$ dan menunjukkan seluruh data pada masing-masing kelompok memilki distribusi normal. Uji homogenitas didapatkan nilai $\mathrm{p}=0,512(\mathrm{p}>0,05)$ yang menunjukkan data homogen pada sebelum pelatihan, sehingga uji hipotesis yang digunakan adalah parametrik.

\section{Uji Beda Rerata Kemampuan Fungsional}

Tabel 3

Uji Hipotesis Paired t-test pada Kelompok I dan II

\begin{tabular}{|c|c|c|c|}
\hline \multirow{2}{*}{$\begin{array}{c}\text { Nilai } \\
\text { Womac }\end{array}$} & Sebelum & sesudah & \multirow[b]{2}{*}{$\mathrm{p}$} \\
\hline & $\begin{array}{l}\text { Rerata } \\
\pm \text { SD }\end{array}$ & $\begin{array}{l}\text { Rerata } \\
\pm \text { SD }\end{array}$ & \\
\hline Kelompok I & $77,7 \pm 5,35$ & $46 \pm 5,53$ & 0,000 \\
\hline $\begin{array}{l}\text { Kelompok } \\
\text { II }\end{array}$ & $74,7 \pm 4,13$ & $35,4 \pm 6,13$ & 0,000 \\
\hline
\end{tabular}

Pada tiap Kelompok memiliki nilai signifikan $\mathrm{p}=0,001(\mathrm{p}<0,05)$ sehingga nilai tersebut menyatakan bahwa pemberian latihan pada kedua kelompok dapat meningkatkan skor kemampuan fungsional pada pasien pasca total knee replacement.

\section{Uji Komparasi Kemampuan Fungsional Sebelum dan Sesudah Latihan antar Kelompok}

\section{Tabel 4}

Nilai Womac sebelum dan sesudah pada Kelompok I dan II dengan

Uji $t$-independent

\begin{tabular}{|c|c|c|c|}
\hline \multirow{2}{*}{$\begin{array}{c}\text { Nilai } \\
\text { Womac }\end{array}$} & \multicolumn{2}{|c|}{ Intervensi } & \multirow{2}{*}{ Selisih } \\
\hline & Sebelum & Sesudah & \\
\hline Kelompok I & $77,7 \pm 5,35$ & $46,7 \pm 5,53$ & $31 \pm 0,12$ \\
\hline KelompokII & $74,7 \pm 4,13$ & $35,4 \pm 6,13$ & $39,3 \pm 1,41$ \\
\hline
\end{tabular}
Nilai p
0,179
0,000
0,001

Hasil analisis beda rerata nilai WOMAC sebelum perlakuan antara masingmasing kelompok dengan nilai $\mathrm{p}$ sebesar 0,179 hasil nilai $p$ lebih besar dari 0,05 ( $p$ > 0.05). Hal ini menunjukkan bahwa tidak ada perbedaan yang bermakna dari hasil pre test antara Kelompok I dengan Kelompok II yang berarti bahwa nilai WOMAC pada kedua kelompok kompatibel. Beda rerata nilai WOMAC setelah perlakuan antara kelompok I dan kelompok II didapatkan nilai p sebesar 0,000 atau nilai $\mathrm{p}$ lebih kecil dari 0,05 ( $\mathrm{p}<$ 0.05). Hal ini menunjukkan bahwa ada perbedaan signifikan antara nilai WOMAC pada ke dua Kelompok I dengan Kelompok II dan menyatakan bahwa Penambahan teknik PNF pada latihan standar fisioterapi lebih meningkatkan skor kemampuan fungsional dibandingkan dengan penambahan PRE pada latihan standar fisioterapi pada pasien pasca Total Knee Replacement

\section{PEMBAHASAN}

\section{Penambahan Latihan $P R E$ pada Terapi Standar Fisioterapi meningkatkan Kemampuan Fungsional}

Belum ada studi yang melaporkan mengenai bahaya penggunaan latihan PRE pada orang sakit seperti : gagal jantung, hipertensi dan peradangan pada sendi ${ }^{7}$.

Subjek dengan keadaan pasca operasi total knee replacement menunjukkan adanya pengurangan kekuatan otot ekstensor lutut 10 - 56\% dibandingkan dengan subjek yang yang seusia dan tanpa patologi terhadap penurunan kemampuan fungsional, bahkan beberapa tahun pasca total knee replacement, kekuatan otot ekstensor berkurang $19-37 \%$ dan sebagian besar pasien tidak mencapai tingkat fungsional ${ }^{8}$.

Progressive resistance exercise (PRE) dapat memberikan efek fisiologis yakni aliran darah ke otot yang bersangkutan meningkat disebabkan peningkatan kebutuhan 
oksigen, nutrisi dan protein lalu diikuti peningkatan serabut otot lurik dan kenaikan jumlah motor unit serta terjadi peningkatan koordinasi intermuscular yang menyebabkan peningkatkan kerjasama antar grup otot dan berpengaruh besar pada peningkatan kekuatan otot yang berdampak kemampuan fungsional yang meningkat ${ }^{6}$

Kelompok I memilki nilai signifikan $\mathrm{p}$ $<0,001 \quad(<0,05)$ sehingga hasil tersebut menyatakan bahwa penambahan teknik PRE pada latihan standar fisioterapi dapat meningkatkan skor kemampuan fungsional pada pasien pasca operasi total knee replacement.

Pemberian PRE pada pasien total knee replacement selama 2 minggu dan rehabilitasi diberikan 1 atau 2 hari pasca operasi, dengan jumlah sampel 14 pasien dengan unilateral TKR diberikan latihan PRE sebanyak $10 \mathrm{RM}$ dengan durasi latihan $3 \mathrm{kali}$ seminggu selama 2 minggu dan diukur dengan kekuatan ekstensi isometrik lutut dan kecepatan berjalan maksimal masing-masing subjek meningkat ${ }^{9}$.

\section{Penambahan Latihan PNF pada Terapi Standar Fisioterapi meningkatkan Kemampuan Fungsional}

Proprioseptive Neuromuscular Facilitation (PNF) berupa latihan yang melibatkan peregangan dan kontraksi kelompok otot yang menjadi sasaran ${ }^{3}$. Kontraksi isometrik yang optimal pada kelompok otot antagonis yang memendek sampai terjadi penambahan Range Of Motion (ROM) dan sampai terjadinya penurunan nyeri ${ }^{4}$.

Pada kelompok II mendapatkan nilai signifikan $\mathrm{p}=0,001(\mathrm{p}<0,05)$ yang menyatakan hipotesis diterima. Jadi hasil tersebut menyatakan bahwa penambahan teknik PNF (Proprioceptive Neuromuscular Facilitation) pada latihan standar fisioterapi dapat meningkatkan skor kemampuan fungsional pada pasien pasca total knee replacement.

Berdasarkan penelitian Amin (2015). Pemberian latihan metode hold relax dapat efektif dalam meningkatkan fleksibilitas otot hamstring karena menstimulasi respon autogenic inhinition. Respon autogenic inhibition akan teraktivasi dikarenakan terjadinya kontraksi maksimum otot hamstring sebagai otot yang ditarget ${ }^{10}$.

Menurut Wiguna et al (2017)

Peningkatan fleksibilitas otot hamstring dipengaruhi oleh faktor lain seperti usia, jenis kelamin dan aktivitas. Peneliti tidak dapat mengendalikan aktivitas diluar latihan sehingga dapat mempengaruhi hasil latihan dan secara umum wanita lebih fleksibel daripada laki-laki ${ }^{11}$.

Menurut Agnieszka et al (2017) terapi PNF selama 2 minggu, termasuk dinamis dan statis menghasilkan mobilitas persendian pinggul yang baik, kekuatan otot, pola berjalan dan pengurangan rasa sakit pada pasien secara positif mempengaruhi fungsi motorik setelah operasi ${ }^{12}$.

Penambahan teknik PNF pada latihan standar fisioterapi akan saling bersinergi untuk membentuk kestabilan, kontrol postural dan melatih respon tubuh yang cepat sehingga terbentuk kemampuan fisik yang bagus yang akan berpengaruh terhadap kemampuan fungsional pada pasien pasca operasi total knee replacement.

\section{Penambahan Teknik PNF Pada Latihan Standar Fisioterapi Lebih Meningkatkan Skor Kemampuan Fungsional Dibandingkan Dengan Penambahan Teknik PRE Pada Latihan Standar Fisioterapi}

Pasien pasca operasi total knee replacement akan menunjukkan defisit kemampuan fungsional yang diakibatkan adanya kekakuan pada otot tungkai bawah disertai rasa nyeri pasca operasi, dengan pemberian latihan dengan teknik Proprioceptive Neuromuscular Facilitation (PNF) yang gerakannya diawali dengan kontraksi isometrik pada otot antagonis, akan berdampak terstimulasinya GTO (Golgi Tendon Organ) sehingga menstimulasi mekanisme inhibitor, akibatnya terjadi 
penurunan impuls motorik pada otot antagonis yang memberikan dampak kinerja otot agonis menjadi turun dan memberikan efek penurunan nyeri..

Reseptor yang terletak diantara tendon dan serabut otot disebut Golgi Tendon Organ (GTO) merupakan reseptor yang berfungsi membangkitkan inhibitori motorik yang menuju otot. GTO akan terstimulasi dengan adanya ketegangan oleh serabut otot, dimana menghasilkan efek meningkatkan fleksibilitas otot hamstring dengan mekanisme yang terjadi pada MSO (Muscle Spindle Organ) dan GTO, MSO sangat sensitif terhadap perubahan panjang otot, yang mana ketika otot terulur berupa respon mempertahankan panjang untuk memelihara postur atau mengubah panjang saat bergerak sehingga keseimbangan tubuh dapat dijaga, keseimbangan baik akan meningkatkan kemampuan fungsional pasien seperti berdiri, berjalan dan menaiki anak tangga ${ }^{13}$.

Penelitian yang dilakukan Birgit et al (2014) meneliti empat studi $R C T$ tentang PRE dan Total Hip Replacement termasuk 136 pasien dan tiga studi $R C T$ tentang PRE dan Total Knee Replacement termasuk 284 pasien. Kesimpulannya PRE aman dan layak sebelum dan setelah Total Hip Replacement, PRE juga aman pada $T K R$ namun tidak ada perbedaan $P R E$ sebelum tapi PRE sesudah TKR menimbulkan efek peningkatan kekuatan otot namun tidak ditemukan efek PRE dapat merangsang GTO ${ }^{14}$.

Perbandingan selisih hasil antara rerata selisih kelompk I $(31 \pm 0,12)$ lebih kecil dari rerata selisih kelompk II $(39,3 \pm 1,41)$. pada kedua kelompok didapatkan nilai $\mathrm{p}=$ $0,000(\mathrm{p}<0,05)$. Hal ini berarti bahwa rerata nilai WOMAC setelah perlakuan di antara kedua kelompok ada perbedaan yang signifikan antara kelompok perlakuan I dan kelompok perlakuan II. Dapat disimpulkan bahwa penambahan teknik PNF pada latihan standar fisioterapi lebih meningkatkan skor kemampuan fungsional dibandingkan dengan penambahan teknik PRE pada latihan standar fisioterapi pada pasien pasca operasi total knee replacement.

\section{SIMPULAN}

1. Penambahan teknik Progressive Resistance Exercise (PRE) pada Latihan standar fisioterapi dapat meningkatkan skor kemampuan fungsional pada pasien pasca Total Knee Replacement

2. Penambahan teknik Proprioceptive Neuromuscular Facilitation (PNF) pada Latihan standar fisioterapi dapat meningkatkan skor kemampuan fungsional pada pasien pasca Total Knee Replacement.

3. Penambahan teknik Proprioceptive Neuromuscular Facilitation (PNF) pada latihan standar fisioterapi lebih meningkatkan skor kemampuan fungsional dibandingkan dengan penambahan teknik PRE pada latihan standar fisioterapi pada pasien pasca Total Knee Replacement.

\section{SARAN}

Perlu dilakukan penelitian lebih lanjut bisa dilakukan dengan cara melihat reaksi biomolekuler ATP yang berhubungan dengan proses peningkatan kekuatan otot pada pasien pasca operasi total knee replacement yang mendapatkan penambahan teknik Proprioceptive Neuromuscular Facilitation $(P N F)$ pada latihan standar fisioterapi

\section{DAFTAR PUSTAKA}

1. Warwick, H., George, A., Howell,C.,Green,C.,Seyler,T.M.,Jiran ek,W.A. 2019. Immediate Physical Therapy following Total Joint Arthroplasty: Barriers and Impact on Short-Term Outcomes. Department of Orthopaedic Surgery.

2. AAOS (American Academy of Orthopedic Surgeon) 2015. Orthopedic Total Knee Replacement. Available 
http://orthoinfo.aaos.org/PDFs/A0037 7.pdf

3. Juliantine, T. 2011. Studi Perbandingan Berbagai Macam Metode Latihan Peregangan Dalam Meningkatkan Kelentukan. Jurnal Universitas Pendidikan Bandung.

4. Victoria, G.D. 2013. The PNF stretching Tehnique - A Brief Review. The journal is indexed in: Ebsco, SPORT Discus, Index Copernicus Journal Master List, Doaj Directory of open acces journalis.

5. Nakata, K., Kougo M., Huo, M. Maruyama H. 2012. The Immediate Effect Of Neuromuscular Joint Facilitation (NJF) Treatment For Knee Osteoarthritis. J Phys Ther Sci 24:6971.

6. Pranatha, I.N.A. 2013. Penambahan Latihan Penguatan Dengan EN-TREE Intervensi Ultra Sound dan TENS Untuk Mengurangi Nyeri Pada Penderita Osteoarthritis Lutut di RSUP Sanglah Denpasar: Universitas Udayana.

7. Kusumawati. 2017. Pengaruh Penambahan Teknik Mulligan Mobilisasi dan Progressive Resistance Exercise Terhadap Peningkatan Aktivitas Fungsional Pasien Osteoarthritis Knee. Skripsi. Yogyakarta: Universitas Aisyah Yogyakarta. .

8. Kasmire, K.E., Rasouli, M.R., Mortazavi, S.M.J., Sharkey, P.F., Parvisi, J. 2014. Predictors of Functional Outcome After Revision Total Knee Arthroplasty Following Aseptic Failure. 21:264-267.

9. Thomas, L.J, Henrik, H, Henrik, K, Thomas, B. 2012 Progressive Strength Training (10RM) Commenced Immediately After Fast-Track Total Knee Arthropoplasty: Is It Feasible?. Department of Physical Therapy.

10. Amin, Achmad, Alfajri. 2015. Metode Active Isolated (AIS) Dan Metode Hold Relax Stretching (HRS) Sama
Efektif Dalam Meningkatkan Fleksibilitas Otot Hamstring Pada Mahasiswa Akademi Fisioterapi Widya Husada Semarang Yang Mengalami Hamstring Muscle Tightnes. Tesis. Bali: Universitas Udayana

11. Wiguna, A.A, Subawa ,W, Dewi, A. 2017.Hubungan Status Kesehatan Berdasarkan WOMAC Dengan Kualitas Hidup Berdasarkan WHOQQOL-BREF Pada Pasien Osteoarthritis Lutut Di Rumah Sakit Sanglah. Intisari Sains Medis, volume 9 number 1 .

12. Agniezka G, Anna S, Mariusz D, Justyna W,Andzelina WN.2017. Assesment The Effect Of The Proprioceptive Neuromuscular Facilitation Therapy On The Improvement Of Motor Function In A Patient After Total Hip Replacement. European Journal Of Clinical

13. Shankar, G., Achnani, Yogita. 2010. Effectiveness of passive stretching versushold relax techniques in flexibility of hamstring muscle, International Journal of Current Research and Review, Vol. 02.

14. Birgit S, Thomas M, Inger M, Per MH, Kjeld S, Ulrik D. 2014.Efficacy Of Preoperative Progressive Resistance Training On Post Operative Outcome In Patients Undergoing Total Knee Arthroplasty 